\title{
ANÁLISIS
}

\section{International Development Assistance as an International Norm: The Japanese Experience}

DOI: 10.32870/mycp.v11i33.313

Arturo Santa-Cruz

\section{Introduction}

International Development Assistance-the transfer of financial, material and/or human resources from rich to poor countries-is today a common practice in international politics. Japan is not an exception to this rule, and it is in fact one of the largest providers of international assistance. Beyond this fact, however, it results particularly interesting to analyze the way in which the above-mentioned practice illustrates Japan's capacity to adapt to the requirements of the international system.

This capacity, of course, is not a novelty: for little more than century and a half, Japan has been a unique member of the international system. Thus, immediately after Commodore Perry's arrival in 1853, Japan had to give up its unique isolationist practice. Established in 1639 by the Tokugawa government, the policy of seclusion or sakoku aimed at limiting the expansion of Christianity in the archipelago and at imposing restrictions to their commerce with the West. Thus, during more than 200 years Japan remained practically without any contact with the outside world. The arrival to Japan

* Profesor Investigador del Departamento de Estudios del Pacífico, del Centro Universitario de Ciencias Sociales y Humanidades de la Universidad de Guadalajara, e investigador del SNI. 
of Perry's black ships served as a catalyst for the changes, which, both in the internal and external fronts would crystallize during the Meiji Restoration that was yet to come.

In the external front, the change was not simply from "isolation" to "coexistence" with other states, but rather one concerning the character that "coexistence" would adopt for Japan. In other words, this was not just some sort of "first encounter" with one or several Western countries (certainly, other European nations had already tried to establish regular contact), as a result of which an equitable relation was going to be established automatically among sovereign states-nations. What was at stake was, precisely, the character this relationship would adopt.

On the domestic scene, the arrival of the American sailors played the role of a catalyst for the powerful forces of change that had been brewing in the Japanese society, as I suggested above. Among the internal transformations that took place, it is necessary to emphasize the adoption of a whole array of Western institutions and practices, ranging from the educational to the post office systems, from segregated public baths to the constitution itself. In order to avoid colonization, a practice that was still common in the second half of the $19^{\text {th }}$ century on the part of the Western powers, what the archipelago did was to adopt a strategy of "defensive westernization."1 It consisted in explicitly imitating Western political and administrative institutions. ${ }^{2}$

By the end of the $19^{\text {th }}$ century, the ambitious process of internal reform had practically concluded. ${ }^{3}$ And on the external scene, the dawn of the $20^{\text {th }}$ Century witnessed a Japan that was capable not only of becoming a military ally of the hegemonic power of the time (the United Kingdom), but also of defeating militarily large nations (China and Russia) and even of becoming, with the acquisition of territories in the region (Korea, Taiwan), the first Asian country to belong to the exclusive club of the imperial powers. There is no doubt, then, that the relative success of Japan in its incorporation to the international system owes to the fact that its leaders recognized the close connection between the internal and external scenes. ${ }^{4}$ Hence, what took

1. Strang 1996, 37.

2. Paul J. DiMaggio and Walter W. Powell, upon discussing institutional isomorphism, refer to the Japanese case of government reorganization as "one of the most dramatic instances."(DiMaggio and Powell 1983, 151).

3. The conclusion in 1899 of the extraterritoriality imposed by the unequal treaties was understood as the reward to the swift Japanese civilizing process (Gong 1984, 181).

4. Iriye 1989. 
place in Japan at the end of the $19^{\text {th }}$ Century and the beginning of the $20^{\text {th }}$ was nothing short of a change of identity. In addition, as Kenneth Pyle has pointed out, the state that emerged from the Meiji restoration "was not a reflection of Japanese society so much as it was an adaptation to the external system." ${ }^{5}$

Similarly, after Japan's catastrophic militaristic adventure of the 1930s, which led first to the invasion of Manchuria and finally to the Second World War-from which it emerged humiliated and brutally defeated-Japan reinvented itself again. The Asian country underwent a surprising endeavor not only of economic, but also political reconstruction. With the occupation forces implementing a "reengineering" of the Japanese political economy, which included no less than their writing of a new political constitution, the Japanese were capable of adjusting to this new institutional framework and of keeping a long period of political stability and economic prosperity. On the international scene, Japan emerged from the occupation as an undoubtedly special nation: one which, by virtue of Article 9 of its new constitution, promulgated in 1948, "gave up" the armed option, entrusted its security to its once enemy, the United States, and re-defined itself as a merchant state.

With the previous examples I intend to convey two ideas: firstly, the evident Japanese capacity to adapt to adverse conditions, and secondly, perhaps the less obvious fact that international politics has structures of its own, to which sovereign states incorporate themselves and transform at the same time. Thus, depending both on the historical moment and on the issue in question, the framework within which state actions occur varies. More specifically, the point is not only that Japan has adapted to the demands of the international system in its diverse array of issues, but also that the structure relevant for the subject-matter of this article, development assistance, is essentially normative in character and that, also on this realm, Japan ended up adopting an external practice-as it will become clear in the reconstruction of this developments I present below.

Hence, although it is valid to argue that the fundamental causal factor of the Japanese adaptation both in the case of Nineteenth-Century Japan (when it was forced by Commodore Perry's "black ships"), and in the case of the Japan of the second half of the $20^{\text {th }}$ Century (this time forced by the presence of the occupation forces commanded by General MacArthur), was

5. Pyle 2006, 397. 
the material structure of the international system (i.e. the distribution of economic or military capacities), in the case of development assistance the story is a substantially different one. In this aspect, the material structure of the international system had little to do with Japan adopting the above mentioned practice. This is precisely the uniqueness to which I was referring previously: Japan's remarkable capacity of adaptation even when it is not demanded at gun point. My central argument is then that external

Although in general terms the history of the Japan that can adapt itself to the requirements of the international system has remarkably recurred once again in recent decades in the case development assistance-the archipelago became the world's largest donor by 1989 - the specificities of this process are quite novel factors, rather than domestic ones, account for the emergence of this practice in Japan. Thus, although in general terms the history of the Japan that can adapt itself to the requirements of the international system has remarkably recurred once again in recent decades in the case development assistance-the archipelago became the world's largest donor by 1989-the specificities of this process are quite novel.

In order to explain this complex process, I divide this article into four sections: The first one is a theoretical discussion on norms in the international system. He-

rein I explain what norms are, why they are important in worldwide politics, and how they spread. It was a specific normative international structure that made the Japanese experience with foreign help possible. The second section discusses briefly the emergence of development assistance on the international scene. It aims at placing the Japanese case in context, emphasizing the international aspect. The third section deals with the domestic structure and the internal impact of adopting the new norm of international cooperation. In the fourth section, I present the conclusions. 


\section{Theoretical discussion}

Norms are collective expectations about appropriate behavior. ${ }^{6}$ In this sense, they are guidelines for behavior or action, and they are generally abided by the members of society. ${ }^{7}$ Nevertheless, norms are not directly observable; therefore, they have to be inferred from actions. This does not mean that a norm should be directly deducible from of a certain action; that is to say, there is not a univocal relation. ${ }^{8}$ Hence, as George Homans pointed out, norms "are not behavior itself, but what people think behavior ought to be." ${ }^{\prime \prime}$ The fact that all human groups feel the need to establish social rules in order to regularize their activities, gives us an idea about why it is important to study them. It is important to bear in mind, however, that norms are not causes in the sense that they unleash this or that event, but rather to the effect that they constitute the conditions necessary for the event in question to be unleashed. ${ }^{10}$

Generally speaking, two types of norms can be distinguished: constitutive and regulative. The former constitute the social actors, in as much as they define them as participants in a given social activity. For example, international normativeness constitutes the international actors, since it prescribes what features they have to fulfill in order to be recognized as such (that is to say, as sovereign states), which means that it establishes who the legitimate participants of the system are. Therefore, constitutive norms create or define forms of behavior at the same time that they "create" the individual himself. ${ }^{11}$ Regulative norms, on the other hand, simply prescribe or proscribe behavior in certain circumstances. The distinction is important because, while it is possible to argue that all the social rules simultaneously constitute and regulate, their effects are different.

Upon constituting the social actors, norms serve as links between discourse and practice. ${ }^{12}$ That is to say, norms are not synonymous with social discourse in the same way as norms cannot be inferred from mere practice-as I pointed out above. In addition, on making clear what is considered valid in

\footnotetext{
6. Jepperson, Wendt and Katzenstein 1996, 54.

7. Ullmann-Margalit 1977, 12.

8. Cancian 1975, 6.

9. Ibídem, 7.

10. Miller 1987, 61-64; Searle 1995, 127-147

11. Foucault 1979, 194

12. Hall and Kratochwil 1993, 486.
} 
a certain moment, norms also provide the function of identifying historical periods, thus emphasizing historicity itself, that is to say, the changing ontology of social action.

Now, saying that norms constitute the actors (whether they are individuals or sovereign states), implies that norms contribute to the formation of their identity. The concept of identity works as a bridge between the normative structures and the actors' interests. In social psychology, the term refers to the images of individuality and personality that the actor has and projects. These images form through time, by means of their interaction with others. ${ }^{13}$ Therefore, identity always exists within a specific context, within a socially constructed world. In this sense, the social process of both the formation and maintenance of identity are determined to a certain extent by social structure. ${ }^{14}$

But: what are the effects of identity? One of the most salient effects of identity is to produce the agents' interests. What an actor wishes is a function of its self-perception. ${ }^{15}$ Moreover, actors have to interpret the structural constraints which they face in a given historical period. ${ }^{16}$ They carry out this interpretation, obviously, in light of their own identity; hence a change of identity has an effect on the actors' interests.

The fact that norms have direct effects on the level of the actors or units of the system does not imply that these should not be considered as a systemic element (and not as a feature of the units). In Anthony Giddens' analysis on the duality of structure, for instance, norms are dealt with as structural properties of society. ${ }^{17}$ Their reproduction is a recursive process in which states' practice reproduces and reconstructs the international system. Normative structures are therefore intersubjective constructions; they are not "objective" as it would be the case of a rock, but neither are they merely subjective, as it would be the case of personal tastes. ${ }^{18}$

Normative structures are thus social facts. ${ }^{19}$ Moreover, in international politics the normative structure operates as a continuum at the domestic

13. Jepperson, Wendt and Katzenstein 1996, 59.

14. Berger and Luckman 1966, 159.

15. Bukovansky 1997.

16. Haggard and Simons 1987, 511.

17. Cf. Cohen 1991.

18. Wendt 1992.

19. Durkheim in Ruggie 1998. 
and international levels. The study of the normative structure bypasses the perennial level of analysis problem in International Relations, since many norms do not operate exclusively on one given level. In this manner, norms serve as a link between the structure itself and the social actors, becoming themselves "units of analysis." ${ }^{20}$ In countless practices, that which is valid at the domestic level—for example representative government—is not alien to what international discourse sanctions; likewise most of the actions that are considered legitimate at the international level-for example, parity representation in some international organizations-have a referent in practices that first became common at the national level. The fact that the international structure is constituted by ideational or normative factors does not mean of course that international politics is benevolent or harmonic. A normative framework can be as exploitative or perverse as the struggle for power in its conventional description; that is to say, in merely material terms. Hegemony, let us remember, is a concept that is not limited to material issues.

Normative or intersubjective structures are constituted by three elements: shared knowledge, material resources and social practices. ${ }^{21}$ Hence, normative structures do not float in the air. They are taken to practice and transformed by specific actors - in the issue in question especially by non-governmental organizations (NGOs), intergovernmental organizations (IGOs) and the states. Therefore, it is important to consider possible mechanisms of change for the normative international structure. The concept of Transnational Advocacy Networks (TAN), coined by Margaret Keck and Kathryn Sikkink is particularly useful on this regard. For them,

A transnational advocacy network includes those relevant actors working internationally on an issue, who are bound together by shared values, a common discourse, and dense exchanges of information and services. Such networks are most prevalent in issue areas characterized by high value content and informational uncertainty. At the core of the relationship is information exchange. ${ }^{22}$

Argumentation is therefore vital for the TAN internal performance. But it is also fundamental for its interaction with other actors. As Thomas RisseKappen has observed, due to the fact that TANs do not have at their disposal

20. Kratochwil 1982.

21. Wendt 1995.

22. Keck and Sikkink 1998, 2. 
substantial material resources, "they have to rely on the "power of the better argument." 23 TANs can then be understood as bridges between state and society. As Keck's and Sikkink's definition suggests, TANs are not integrated exclusively by non-state actors, such as NGOs or religious organizations. They can also include state agencies and even intergovernmental organizations. This means that TANs are not in a external position vis-à-vis the state or the international system. As Keck and Sikkink write, "Because parts of states and international organizations also participate in these networks, this process of negotiation within the emergent cosmopolitan community is not "outside" the state." 24

TANs may be considered in their dual nature: as a structure and as an agent. As the former, they establish a pattern for their members' interaction and permeate them with identity; as the latter, they launch specific proposals of public policies in the international arena. The key to this double character lies on their organizational arrangement, which is both decentralized and horizontal, and on the type of strategy that they use. The core of the network is neither a bureaucratic apparatus nor a social base in continuous movement, but rather a small group of political businessmen who concentrate on specific events and, especially, on the information that their members exchange. The social nature of the information compiled-and therefore constructedbecomes the raw material for a new discourse.

Although TANs are not state actors, their action affects interstate politics. As I suggested previously, the states' internal sovereignty is intimately related to their social substratum. Turning our attention back to one of the international system's fundamental norms, the evolution of sovereignty is clear on this matter: from being a "principle" of proper behavior among states in the $18^{\text {th }}$ century, by the $20^{\text {th }}$ century it had become "a territorial ideal," in which the focal point was the relation among territory, power and accepted forms of political organization. ${ }^{25}$ This transformation had profound consequences both for the way in which states related to one another, and for the way in which they related to their people. It is then through the practice of both state and non-state actors that the system of states is reproduced and transformed.

23. Risse-Kappen 2000, 20.

24. Keck and Sikkink 1998, 216.

25. Murphy 1996, 91. 
Another way of analyzing TANs is in terms of structures (that is to say, in connection with the framework formed by NGOs, IGOs and the states in particular issue-areas), is the concept of Political Opportunity Structure (POS). Although the term originated in the analysis of political issues at the national level, it can be used, with all the due safeguards, at the international level. The very existence of issue-areas that are more or less compartmentalized, in which there is certain governability, suggests the applicability of the term to international politics. Sydney Tarrow defines the term as "consistent-but not necessarily formal, permanent, or national—dimensions of the political environment that provide incentives for people to undertake collective action by affecting the expectations for success or failure." ${ }^{26}$ At the international level, Jackie Smith has written that "transnational political opportunity structures influence movements' capacities for mobilization as well as their strategic alternatives." ${ }^{27}$

Hence, even if they are not the equivalent to the POS, which are produced at the national level, in as much as there are "supranational arenas" in some issue-areas, it is arguably valid to speak about the existence of POS in world politics. ${ }^{28}$ Mutatis mutandis, the symbiosis POS produces at the national level takes place as well at the global one. As Tarrow has written, "Like the national state that grew in the nineteenth century, international institutions provide new and alternative opportunities for collective action to a host of social actors but at a higher level." 29

\section{The Interstate Scene}

Development assistance emerged at the end of the 1950's in the rich countries of Europe and America. ${ }^{30}$ The rationale of the new practice had to do obviously not only with the solidarity of the developed countries with what in those years had began to be called "third world, " but also with the Cold War rivalry. Not only did the United States need to legitimize its hegemony and win followers by means of generous programs of international cooperation, but it was also important that friendly countries take part in this emerging

26. Tarrow in Hipsher 1996, 275-276.

27. Della Porta and Kriesi 1999, 18.

28. Ibid., 19.

29. Tarrow 1996, 11.

30. White $1974,11$. 
practice. In the struggle for world public opinion, this type of actions had more than a symbolic value. With this I am not implying that cooperation for development was simply an empty practice imposed by Washington on its allies. Undoubtedly, Western European countries had their own motives-not the least of which was the legacy of the alleged "white man's burden." What I suggest is simply that this normative (and strategic) factor of international politics not be overlooked when analyzing the emergence of this practice.

Thus, since the mid 1950's - even before it was a prosperous country-Japan undertook aid programs. ${ }^{31}$ These resources were intended fundamentally for programs of post-war repairs in former colonies in Southeast Asia, in accordance with the San Francisco Peace Agreement of 1952. ${ }^{32}$ Significativelyconsidering the previous experiences the country had had at adopting itself to international demands, as noted above-in 1961 Japan joined, as a founding member, the Development Assistance Committee (DAC) of the so-called "club of the rich," the Organization for Economic Cooperation and Development (OECD) —even though it was not yet a member of this organization. ${ }^{33}$

This measure showed Japan's determination "to be accepted as a responsible member" of the international community. ${ }^{34}$ As Amy Gurowitz has noted, "an ongoing theme in Japanese state identity since the Meiji period has been to avoid being alienated" from the Western powers. ${ }^{35}$ Nevertheless, Japanese leaders joined the club of the world's benefactors out of pragmatism rather than out of good will. According to John White, their intention to improve the archipelago's image was what motivated them to participate in the development assistance field. ${ }^{36}$ Thus, in 1972 an internal document of the Ministry of Foreign Affairs (MOFA) admitted that Japan had been practically forced to grant aid to other nations. ${ }^{37}$

Once development assistance had a place in international politics, not only at the normative and discursive levels, but also at the institutional one, OECD countries took another important step in the evolution of this practice.

31. Drifte 1998, 127.

32. Ibid.

33. Japan joined the OECD in 1964.

34. Rix 1980, 28.

35. Gurowitz 1999, 424.

36. Rix 1993, 29.

37. Rix 1980, 39. 
Since the late 1960's and the beginning of the 1970's, they started cooperating with the nascent International-Development NGOs (IDNGOs).

IDNGOs made use of the POS created both at the national level and intergovernmental levels by the rich countries. This way, as Kim Reimann has observed, the idea that it was convenient to include IDNGOs and ONGs in the official foreign aid programs became popular among the DAC member countries, especially since the 1980's. ${ }^{38}$ IDNGOs' newly acquired importance was part of a broader phenomenon: the increasing role NGOs had on a global scale. As Kenneth Boulding pointed out in 1989, "the rise of international non-governmental organizations [is] perhaps one of the most spectacular developments of the twentieth century." ${ }^{39}$

Nevertheless, once again Japan was an extreme case in the developed countries' universe. The motives behind the increasing cooperation between IDNGOs and donor states were numerous: from the point of view of the government in question, the civil organizations offered the advantage of possessing highly specialized local knowledge, as well as the possibility of bypassing authoritarian governments in target countries. ${ }^{40}$ For the IDNGOs, their joint work with the governments represented a valuable recognition that provided them with legitimacy, as well as with an important source of resources. Therefore, by the late 1990's, OECD member countries were channeling approximately five per cent of their official aid through IDNGOs. The extreme case is undoubtedly that of Sweden, whose percentage in this matter amounted to 85 points. ${ }^{41}$ The symbiosis between state and non- state actors was making it clear that a TAN was emerging in this field.

Moreover, not only states, but also IGOs started collaborating with NGOs in general and with IDNGOs in particular. This way, at least since the World Food Conference held in November 1974, the relation between intergovernmental and non-governmental instances with an international calling remained firmly established. From that moment on, these independent groups started receiving legitimacy, and they were even invited to take part in some governmental deliberations. ${ }^{42}$ Approximately a decade later, DAC began to

38. Reimann 2003, 306; Hirata 2002, 28.

39. Iriye $2002,159$.

40. Kaldor 2003, 87-88.

41. Ibíd., p. 89.

42. Van Rooy 1997, 98. Although institutionalization of social representation through NGOs at the United Nations system level had been going on for quite a while. Still, its exponential 
refer to IDNGOs as "partners in the development field," and other IGOs such as the World Bank started collaborating with IDNGOs. ${ }^{43}$

Thus, while state organizations created the functional equivalent-at the international level — of a POS, a veritable TAN was consolidating in the "participatory development" field. ${ }^{44}$ This way, the collaboration between the civil society and the state in development assistance projects was already not just a common feature of the developed countries, but rather, with the participation of the IGOs, it had become a new international norm-a norm in whose dissemination, although financial resources were actually transferred, it is worthwhile repeating the distribution of capacities per se was marginal.

Japan's anomalous situation on this matter had become apparent by the late 1980's. Once again, Japan started its process of adapting to international standards. Unlike the cases of the end of the $19^{\text {th }}$ century or the mid $20^{\text {th }}$ century mentioned above, in this case states had lost their relative weight-or at least they were not the only relevant actors anymore. That is to say, by the end of the $20^{\text {th }}$ century the emergence of a myriad of civil society groups on a global scale was a fact on the ground, which had turned them into important actors on the international scene. In the following section, I will deal with the domestic aspect of the diffusion norm in question in a more detailed way, analyzing more thoroughly the Japanese domestic structure. For the time being, I am interested in emphasizing the interstate aspect of the Japanese adoption of the norm in question, both from the state's point of view as well as from that of the so-called "international civil society."

In spite of above mentioned upspring of diverse civil society groups in world politics, the existence of the "international civil society" as an amalgamated entity is a project rather than a reality. ${ }^{46}$ Therefore, the leading role in the norm's diffusion process as to the way in which development assistance ought to be carried out was played by states and IGOs. This way, the pressure from the Japanese state's counterparts started increasing at the moment when the Cold War was coming to an end. Although aid to poor countries had been a strategic imperative at the beginning of the bipolar age, it was replaced by the generosity of the state/ civil society association. It is

growth coincided with the INDGOs' heyday; Cf. Clark, Friedman and Hochstetler 1998, 6.

43. Reimann 2000, 12.

44. Ibid.

45. Kaldor 2003; Halperin and Laxer 2003; Walzer 1995.

46. Halperin and Laxer 2003, 9. 
worth remembering that in the events leading to the fall of the Berlin Wall, civil societies of Central and Eastern European countries emerged as heroic protagonists in international public opinion. Thus, in OECD countries it was imperative to show a determined support to NGOs, which had become the most visible-and at times the most docile-representatives of the civil society at the international level.

At the beginning of the 1990's, DAC started issuing reports about the extent to which member countries were promoting "participatory development." By that time, it must be pointed out, Japan had not only become a new world economic power, but also the programs in which its government involved NGOs were still quite modest. Similarly, in 1993 the United States became an important member of the new paradigm of cooperation, and launched the Common Agenda for International Cooperation from a Global Perspective program. ${ }^{47}$

Meanwhile, the Japanese diplomats felt the international pressure and started taking steps to adapt to the new international normative environment in the matter. Thus, since the end of the 1980s the yearly MOFA reports on foreign aid began to mention the advantages of collaborating with the NGOs. Significatively, these reports made explicit comparisons with Western countries regarding civil society- government interaction. ${ }^{48}$ In 1987, Prime Minister Nakasone Yasuhiro established an Advisory Council in order to improve his government's policies on development assistance; the Council recommended that the government develop financing schemes for Japanese IDNGOs. ${ }^{49}$ In the 1991 "white paper" on Official Foreign Aid (OFA), the Japanese foreign ministry admitted that the reform in this matter was necessary not only for humanitarian reasons, but also for explicitly recognizing the state of interdependence between the country and international society ${ }^{50}$. In 1992, the government revealed its new agenda for development assistance, the Official Foreign Aid Charter. In it, controversial issues such as democracy, environmental protection and unemployment, appeared in the context of then still nascent new world order. ${ }^{51}$ On this matter, though, Japan was also adapting to wider trends. Thus, for instance, Miranda Schreurs has noted how,

47. Reimann 2003, 310.

48. Ibid., 309.

49. Ibid., 309-310.

50. Rix 1993, 14.

51. Pharr 1994, 165. 
largely as a response to external pressure, the Japanese government took the leading role in the field of environmental protection. ${ }^{52}$

Hence, as Kent Calder put it in 1988, Japan seems to be a "reactive state". ${ }^{33}$ This attitude is partially explained by the structural position the country has in the international system. In this context, Japan has made a virtue of necessity. Kosaka Masataka explained it this way:

Japan is a natural nation-state; the idea that a state is created by a common will and contract has not existed in Japan. Japan has existed and will exist, regardless of the will and action of its people. Hence, norms are considered to be created by nature, not men...The logical conclusion from such a view of the world is that the task for the Japanese is to adapt wisely to the international situation to secure its national interests, and not try to change or create the mysterious framework. ${ }^{54}$

In a similar way, former Japanese Prime Minister Miyazawa Kiichi maintained that Japanese foreign policy "precludes all value judgments...the only value judgments we can make are determining what is in Japan's interest...we watch the world situation and follow the trends." 55

Therefore, the Japanese ability to adapt to international norms must be understood as something more than the simple result of external pressure (gaiatsu). If that were the case, international norms would simply affect Japan's behavior in an ephemeral and superficial manner. The former because as soon as the pressure disappeared, Japan would return to its previous habits: the latter because the changes would not become institutionalized. Nevertheless, I argue that Japan's adoption of the international assistance norm has indeed caused changes in its identity and interests. That is, what has taken place in this regard is a socialization process. This does not contradict what I said earlier about Japan's foreign policy, nor does it mean that Japan is a mere puppet of international dictates. The situation is more complex than that. As Miyashita Akitoshi and Sato Yoishiro have demonstrated, more often

52. Schereurs 2002, 217-218.

53. Calder 1988.

54. Pyle 2006, 406.

55. Ibid., 414 . 
than not what appears as the result of mere gaiatsu is actually a question of choice, of deliberate policies on the part of the Japanese government. ${ }^{56}$

International pressure (both through the network for development assistance as well as through the corresponding norm concerning the state's cooperation with the IDNGOs) and the subsequent adoption on Japan's part of the new paradigm of international cooperation has had, of course, effects on the Japanese domestic structure. For the time being, I am interested in emphasizing herein that by 1989 Japan had already become the world's largest donor. ${ }^{57}$ Development assistance is now the concern of a wide variety of state institutions, such as the Japan International Cooperation Agency (JICA), the Export-Import Bank of Japan, and the Overseas Economic Cooperation Fund. ${ }^{58}$ To different extents, these and other state institutions interact with Japanese and foreign NGOs. In 1994, MOFA established the Division for NGO Assistance, and increased the number of resources originally allotted to them by about 1000 per cent during the following three years. ${ }^{59}$ Another highly significant step, this time on the international scene, took place in 2000, when Japan hosted the yearly meeting of the Group of the 7, with its government including ONGs for the first time in this type of events-and even designating an "Ambassador in Charge of Civil Society."60

\section{Domestic Structure and Internal Impact of the New Norm}

The diffusion process of the norm regarding the state-civil society association in development assistance projects had a different dynamics on the internal scene. That is to say, when the POS in question is not the international but the domestic one, it can be easily observed that this norm evolved at a much slower pace than that suggested by the mere consideration of its external counterpart-and also that in this regard Japan's domestic structure acquires greater relative weight. It is well known that in Japan there has been a consensus in favor of state policies that place the country on a par with the Western powers in the economic field, a consensus that has been largely made possible by the existence of what, at least from abroad, can be perceived as a

56. Miyashita 2001, 58.

57. Drifte 1998, 114.

58. Ibid., 115.

59. Jain 2000, 31.

60. Reimann 2001, 128. 
collusion between interest groups with political parties-especially with the Democratic Liberal Party, the hegemonic one since the Cold War years-and with a powerful and efficient bureaucracy. ${ }^{61}$ Let us begin by briefly analyzing the concept of domestic structure, reviewing the discussion about statesociety relations, in order to set out in a more detailed fashion the character and evolution of Japanese civil society.

By domestic structure I refer to "the normative and organizational arrangements which form the 'state', structure society, and link the two in the polity." ${ }^{2}$ In this respect, it is important to consider: 1 ) the degree of centralization (or fragmentation) of the political institutions (i.e., the state), 2) the social polarization in terms of social or ideological fissures, which bring about the structure of demand-formation in the civil society, and finally 3 ) the policy networks made up by intermediate organizations (e.g. labor unions or political parties), which serve as a bridge between state and civil society. ${ }^{63}$ The three previous criteria allow us to establish a matrix with six ideal types of domestic structure. Thomas Risse-Kappen and his collaborators have labeled the Japanese domestic structure as "corporate," which is characterized by the existence of powerful intermediate organizations operating in a political culture oriented towards consensus - a context which propitiates political agreements. ${ }^{64}$ Importantly for the interaction between the domestic and the international realms, is that it is quite probable that the impact of the international actors who manage to penetrate this domestic structure will be lasting, as corporate-like domestic structures tend to institutionalize social and political agreements. ${ }^{65}$

Referring specifically to the Japanese case, Peter Katzenstein and Tsujinaka Yutaka have noticed a kind of balance between the state's autonomy and its immersion in civil society-what Richard Samuels has called a system of "reciprocal consent." 66 This normative context, they note, lies in the implicit understanding that national politics should serve the country's national interests in the long run-which would imply a close state-society relation-

61. Kingston 2004, 21.

62. Risse-Kappen 1995, 6.

63. Ibid., 22-23.

64. Ibid., 24.

65. Ibid.

66. Katzenstein and Tsujinaka 1995, 84. 
ship. ${ }^{67}$ However, the traditional state-civil society dichotomy definitely does not work in Japan.

In the Japanese case, the civil society- state symbiosis suggested above is conspicuous. It is often assumed that the civil society is in an external position or in opposition with regard to the state, and that when such is not the case the anomaly is due to state co-optation of (an immature) civil society. Nevertheless, more often than not such apparent externality is only an "effect." As Timothy Mitchell has suggested, it is the daily practices, always changing depending on the time and on the specific issue, that produce the structural effect by means of which the state appears as an independent entity, apart from society. But as he points out, "the boundary of the state (or political system) never marks a real exterior." ${ }^{\text {" }}$ Nevertheless, instead of simply disregarding the concept of "state," as pluralists used to do, or of considering it merely as discourse, as postmodernists suggest now, it makes sense to keep on using it, because it confronts us objectively as a social structure, yielding real effects.

Thus, as Joel Migdal has pointed out, the modern state's paradox is that the individuals' adherence to an entity they feel they are a part of is constantly put to test by the entity itself, an entity that simultaneously seems to be apart from the society. ${ }^{69}$ No matter how ethereal it may seem, this point has at least three very concrete analytical implications, particularly in connection with the issue in question now. On one hand, it helps to understand the corporate character of the Japanese domestic structure, in which the barriers between state and society are always porous. On the other hand, it also contributes to explain better the organic metaphor mentioned previously, which dispenses with the incisive state-society division. Nationalism, or in the Japanese case, the racial homogeneity artifice, is a common resource used in order to dispel the effect of state's exteriority, and in this way transform society, as John Breuilly has pointed out. ${ }^{70}$ The state, as an expression of national sovereignty, thus tries to become an extension of its citizens' identity. Finally, the modern state's paradox also contributes to the understanding the changing character of both state and civil society.

67. Ibid.

68. Mitchell 1991, 90.

69. Migdal 1997, 226-227.

70. Ibid., 227. 
As Robert Pekkanen has noticed, "the state shapes civil society everywhere." ${ }^{71}$ But in fact co-determination runs both ways. That is to say, the state is a part of society, and it may contribute to its make-up, but it is also constantly transformed by the society in which it is immersed..$^{72}$ Although the Japanese state is generally considered, not without reason, as a strong one, it is important to bear in mind that this strength comes largely from its close relation with society. Therefore, the state's strength implies, by definition (since state and civil society are interdependent concepts, though not necessarily antagonistic ones), a relatively weak civil society. Thus, if as Christopher Bryant has pointed out, nations that imagine themselves more in ethnic terms than in civic ones-as it has undoubtedly been the case of Japan-can have problems building a robust civil society, the conventional wisdom on the relatively weak Japanese civil society does not seem to be completely mistaken. ${ }^{73}$ As Hirata Keiko has written, "Almost every knowledgeable observer would agree that throughout Japanese history civil society has remained extremely weak vis-à-vis the state." 74

Although with the previous statement Hirata is not implying that state and civil society play antagonistic roles, I would argue that it would be necessary to qualify it. ${ }^{75}$ In comparison with those of other developed countries, and considering the type of associations most common in these societies, Japanese civil society definitively seems weak. Nevertheless, once we break down civic participation into activities or types of association, things start looking different. Thus, the civil society that is the most visible from the outside, the one that at any rate is an actor in the matter at hand, has indeed developed only recently. As Hirata puts it, "Japan represents an extremely interesting case of the intersection of non-Western culture, rapid industrialization, subsequent economic recession, and the rise of civil society;" it is a process that has taken place especially in the last two decades.

As Pekkanen has observed, what happens in reality is that Japan has a "dual civil society:" one made up by a myriad of small associations whose aim is to face issues of their immediate community, and other-the one

71. Pekkanen 2006, 5 .

72. Migdal 1994, 2.

73. Bryant 1995.

74. Hirata 2002, 8.

75. Ibid., 5 .

76. Ibid., 1. 
which tends to attract more attention in the West-whose aim is of a more cosmopolitan nature, but whose magnitude is rather modest. ${ }^{77}$ In his words, "the major feature of Japan's civil society [is the existence] of many small local groups and few large professional groups." ${ }^{78}$ Hence, simply stating that Japanese civil society is weak is incorrect.

Yet, the state's role in its general configuration, that is to say, both at the level of the small groups as well as that of the biggest and professional ones, has been determining. More specifically, the POS has had direct effects on civil society's bifurcation. The Japanese POS had become, at least until recently, an insurmountable obstacle for the development of groups such as IDNGOs in terms similar to those of their peers in other developed countries. Firstly, through the regulations imposed on civil society groups (something I will turn back my attention to later on) the POS has structured the "consistent dimensions to the political environment which either encourage or discourage people from using collective action"79 This way, upon managing the incentives, the state partially molds the organization of civil society. "The pattern of dual civil society organization that we see in Japan today is explained by Japan's political institutions." ${ }^{80}$ More specifically, at the actors' level the POS that the Japanese civil society faces is composed by a relatively isolated bureaucratic apparatus, and by a legislature that is relatively uninterested in the formation of independent civil groups. ${ }^{81}$ The fact is that Japanese people participate in a differentiated manner in diverse types of organizations.

However, this has also been changing. Thus, since 1991, the year in which the government established the Postal Savings for International Voluntary, administered by the Ministry of Post and Telecommunications, IDNGOs projects can receive public financing by this means. By the mid 1990's, more than 180 organizations had undertaken 240 projects under this scheme. ${ }^{82}$ Based on the important Japanese tradition of using the postal service as a recipient of popular savings, this is the most original financing program es-

77. Pekkanen 2006.

78. Ibid., 24.

79. Tarrow in Pekkanen 2006, 19.

80. Ibid., 2.

81. Ibid., 20.

82. Uchida 1996, 90. 
tablished by the government. ${ }^{83}$ Since the beginning of the 1990 's the growth of Japanese civil society has become more conspicuous.

But it has been mainly since the 1995 Hanshin-Awaji (Kobe) earthquake, when more than one million volunteers took part in the rescuing efforts at a time when the government proved unable to act rapidly and efficiently, that Japanese civil society, in its two variants, has acquired an unusual heyday. As a result of this tragic event, state-society relations have been re-defined in an important way. Thus, in 1998 the Special Law for Non-Profit Activitiesbetter known as the Law for Non-Profit Organizations-was passed (NonProfit Organizations is the term by which NGOs concerned with domestic matters are commonly referred to in Japan); the new law amended the one that until then had regulated the activities of this type of organizations: the 1896 Civil Code. ${ }^{84}$ The new legislation made it substantially easier for civil organizations (whether they were NGOs or NPOs) to obtain legal recognition. Without this recognition, the life of these groups was of course much more complicated. For example, one person in particular, not the organization as such, had to assume full legal responsibility on signing a lease contract or on hiring a telephone line. ${ }^{85}$ Obtaining government funding was also much harder without official recognition.

The spontaneous reactions of solidarity on the part of civil organizations helped to increase their legitimacy in the eyes of public opinion. Asahi Shinbun, one of the major Japanese newspapers, for example, demanded that the government pay more attention to these organizations; 1995 was indeed declared "The year of the Volunteer." ${ }^{16}$ Therefore, Japan has not been allied to the wider pluralist wave that has swept the world in the last few decades. ${ }^{87}$ Though in 1990, according to the directory of the Japanese NGOs Agency for International Cooperation (JANIC), there were less than 150 IDNGOs, eight years later that number had more than doubled, reaching $368 .^{88}$ As it was to be expected, nowadays independent civil groups exert a greater influence on the public policy making process than two decades ago. According to Hirata,

83. Menju and Aoki 1996, 151.

84. Hirata 2002, 14.

85. Kingston 2004, 73.

86. Jain, 2000, 26-27; Pekkanen 2000, 114.

87. Jain 2000, 37.

88. Rix 1993, 67-68; Jain 2000, 18. 
"civil society actors have found shared goals with state officials and have begun to cooperate with the state, when necessary, on equal terms." ${ }^{99}$

Perhaps this is too optimistic a vision, but at least in what respects the development assistance field, it is clear that state-society relations have changed substantially in the last few years. Not too long ago, in 1989, the Japanese government prohibited Japanese NGOs from taking part in an international conference on global environmental protection held in Tokyo. ${ }^{90}$ But now, as Hirata has pointed out, "Japanese NGOs are more involved in ODA policy issues than in any other foreign policy issue in Japan." ${ }^{91}$ Thus, as I noted above, in the last decade the Ministry of Foreign Affairs has established the Division for NGOs Assistance. In keeping with this line, in 1994 for the first time NGOs representatives were included in a Japanese delegation (to the UN International Conference on Population and Development in Cairo). ${ }^{92}$ The government included again NGOs representatives in 1995, both in the World Summit for Social Development held in Copenhagen, as well as in the World Conference on Women in Beijing. This practice became regularized and, in 1997, regular meetings were established between the Ministry of Foreign Affairs and NGOs representatives. In 1999, as a result of the interaction between government bodies and NGOs, the government started subcontracting them on a regular basis to carry out development assistance projects. ${ }^{93}$ Therefore, foreign policy is not the Japanese government's exclusive prerogative anymore. This change has been perceived even by some politicians-who have acted accordingly. For example, some legislators formed the Federation of Parliamentarians to Promote NGOs International Cooperation. ${ }^{94}$

The change in state-society relations - at least regarding IDNGOshowever, does not seem to have affected the peculiarities of the Japanese civil society as far as size is concerned. Thus, Kim Reimann found out that the average income of the major Japanese IDNGOs was, by the end of the 1990's, hardly more than three per cent that of their American counterparts. ${ }^{95}$ As Pekkanen has pointed out, Japanese IDNGOs have fewer personnel, fewer

89. Hirata 2002, 3.

90. Jain 2000, 29.

91. Hirata 2002, 3.

92. Jain 2000, 27.

93. Hirata 2002, 139.

94. Jain 2000, 18, 34 .

95. Own calculation based in Reimann 2003, 298-299. 
offices abroad and, in general, a much more reduced presence in other countries. For example, the major American IDNGOs have approximately 100 times more personnel than their Japanese counterparts. ${ }^{96}$

Maintaining their own characteristics, and within the framework of the new POS, Japanese IDNGOs have worked closely with their counterparts in other countries. With this effort, they have contributed to the consolidation of a TAN in the last few years. Just as the Japanese state was mainly influenced by other states, Japanese NGOs have been influenced by their peers in other countries - and they have created a network in this field. ${ }^{97}$ In this manner, the new norm is present not only internationally at interstate level, but also at the non-state one, and even in the interaction between NGOs and IGOs. This triple relation has been the basis both for the formation of the above-mentioned TAN in the field, and for the creation of new IDNGOs in Japan. ${ }^{98}$ That is why the new norm has acquired relevance in Japanese political economy. As Gurowitz has pointed out, "international norms can matter only when they are used domestically and when they work their way into the political process." 99

Nevertheless, the process for adopting the new international norm about the way to carry out development assistance has occurred mainly from the top down. That is to say, the state, mainly impelled by the international normative structure, has been the determining force in its adoption. As I was told by an official from the MOFA NGOs Division who asked that his name not be revealed, the constant interaction with the NGOs is explained largely "by the international norms [prescribing] that we have to collaborate with NGOs." 100

In addition, for the Japanese Foreign Ministry, development assistance, even undertaken with the participation of IDNGOs, is fundamentally the state's business, whose objective it is to see to the state's "national interests". ${ }^{101}$ Therefore, even in the renewed POS that frames the relation between government and IDNGOs, the former keeps on playing the leading role. This does not mean that IDNGOs, at least not all of them, are simply governmental

96. Pekkanen 2006, 39-40.

97. Hirata 2002, 4, 45.

98. Reimann 2001, 12.

99. Gurowitz 1999, 416.

100. Interview, Tokio, 19 July 2006.

101. Hirata 2002, 140. 
appendices or "GONGOs "(Government Organized Non Governmental Organizations). As Kim Reimann points out, Japanese IDNGOs were, on average, much less dependent on the Japanese government than their American counterparts were on their own government. ${ }^{102}$ Undoubtedly Japan lived through important changes during the so-called "lost decade" of the 1990's; in social terms, however, the radical changes that did occur did not bring about any loss, but rather the dividends of a strengthened civil society. ${ }^{103}$

What results interesting, in any case, is that this process of convergence has meant, in practice, the moderation of what used to be the earlier "citizens' movement." Although some NGOs still believe that the MOFA tries to use them simply to reduce costs, the fact is that cooperation has increased. ${ }^{104}$ That is why authors, such as Mary Kaldor, sustained that the present NGOs are in fact the "domesticated" versions of their most radical predecessors. ${ }^{105}$

\section{Conclusions}

In the case development assistance, Japan has demonstrated once again its capacity to adapt itself to the demands of the international system. As the above arguments set out clearly, Japanese participation in this practice obeyed more to external factors than to domestic ones. To begin with, Japan started granting foreign aid before reaching the levels of prosperity enjoyed by the rich countries of Western Europe or the United States, which inaugurated development assistance. But once Japan fulfilled this external requisite, it did so in accordance with its own peculiarities. Thus, approximately three decades after Japan had adopted the development assistance practice some adjustments had to be made once again.

This time, the international requirement had to do with the social changes that the ever-increasing globalization and the end of the bipolar era had brought about. Japan's Western counterparts had started incorporating non-governmental organizations into their foreign aid programs years earlier, and by the last decades of the $20^{\text {th }}$ century, the archipelago was falling behind

102. Reimann 2003, 314.

103. Kingston 2004, 2.

104. Hirata 2002, 140-141.

105. Kaldor 2003, 94. 
regarding international standards on the matter. So, once again because of external pressure rather than because of a strong demand from its society, the Japanese government started including in a more conspicuous way members of civil society in their programs for foreign cooperation.

With this I am not suggesting that Japan should be seen as a puppet that automatically follows the dictates of international politics. As I documented in the previous sections, Japanese society itself has a long tradition of independent organization - if with features that are very different from those that prevail in the Western countries - that, far from remaining static, has evolved and, up to a certain extent, converged with the Western practices. Thus, the reshaping of development assistance-due in part to recent changes in Japanese civil society-took place according to the country's own cultural patterns.

The theoretical discussion presented in section two should make the process described above somewhat more intelligible. Taking the normative element of the international system into consideration helps understanding the importance of aspects that, from a merely materialist point of view, would appear irrelevant or simply go unnoticed. Furthermore, extrapolating the POS concept to the international level contributes to evince the normative scaffolding in which state and non-state actors interact. Similarly, the literature on TANs helps grounding the more abstract discussion on norms and structures, bringing actors back-in. Analogously, the notion of domestic structure helps in appraising both the degree and manner in which international norms are adapted by the country in question. Finally, problematizing state-society relations contributes to demystify and contextualize what often seems as an entity both ethereal and omnipresent: the state. Putting these analytical tools to work in this particular case of the development assistance field should thus have made my initial statement patent: Japan's remarkable ability to adapt itself to the requirements of the international system. miv

\section{References}

Berger, Peter and Thomas Luckman. 1966. The Social Construction of Reality. A Treatise in the Sociology of Knowledge. Garden City, N.Y.: Doubleday. Bryant, Christopher G. A. 1995. Civic Nation, Civil Society, Civil Religion. In

Civil Society. Theory, History, Comparison, 136-157. Edited by John A. Hall. Cambridge: Polity Press. 
Bukovansky, Mlada.1997. American Identity and Neutral Rights from Independence to the War of 1812. International Organization 51(2): 209-243.

Calder, Kent. 1988. Japanese Foreign Economic Policy Formation: Explaining the 'Reactive State'. World Politics 40: 517-541.

Cancian, Francesca M. 1975. What are Norms? Cambridge: Cambridge University Press.

Clark, A. M., E. J. Friedman and Hochstetler. 1998. The Sovereign Limits of Global Civil Society: A Comparison of NGO Participation in UN World Conferences on the Environment, Human Rights and Women. World Politics 51: 1-35.

Cohen, Ira J. 1991. Teoría de la estructuración y praxis social. In La Teoría Social, Hoy. Edited by Anthony Giddens and Jonathan Turner. México: Conaculta-Alianza Editorial.

Della Porta, D. and H. Kriesi.1999. Social Movements in a Globalizing World: An Introduction. In Social Movements in a Globalizing World, 3-22. Edited by D. della Porta,

H. Kriesi and D. Rucht. London: MacMillan.

Di Maggio, Paul and Walter W. Powell. 1983. The Iron Cage Revisited: Institutional Isomorphism and Collective Rationality in Organizational Fields. American Sociological Review 48: 147-160.

Drifte, Reinhard. 1998. The Use of Soft Power in Japan's Foreign Relations. Houndmills, Basinstoke, Hampshire and London: MacMillan Press.

Foucault, Michael. 1979. Discipline and Punish. Nueva York: Vintage Books.

Gong, G. W. 1984. The Standard of Civilization in International Society. Oxford: Clarendon Press.

Gurowitz, Amy. 1999. Mobilizing International Norms: Domestic actors, Immigrants, and the Japanese State. World Politics 51:413-445.

Haggard, Stephan and Beth A. Simons. 1987. Theories of International Regimes. International Organization 41(3): 491-516.

Hall, Rodney Bruce and Friedrich Kratochwil. 1993. Medieval Tales: Neorealist 'Science' and the Abuse of history. International Organization 47(3): 479-491.

Halperin, S. and G. Laxer. 2003. Effective Resistance to Corporate Globalization. In Global Civil Society and Its Limits, 1-21. Edited by S. Halperin. London: Palgrave, Macmillan. 
Hipsher, P. L. 1996. Democratization and the Decline of Urban Social Movements in Chile and Spain. Comparative Politics 28(3): 273-297.

Hirata, Keiko. 2002. Civil Society in Japan. The growing role of NGOs in Tokyo's aid and development policy. New York: Palgrave Macmillan.

Iriye, Akira. 1989. Japan's Drive to Great Power Status. In The Cambridge History of Japan, Vol. 5, 721-782. Edited by Marius B. Jansen. Cambridge: Cambridge University Press.

_- 2002. Global Community: The role of International Organizations in the Making of the Contemporary World. Berkeley: University of California Press.

Jain, Purnendra. 2000. Emerging Foreign Policy Actors: Subnational Governments and Nongovernmental Organizations. In Japanese Foreign Policy Today, 19-39. Edited by Inoguchi Takashi and Purnendra Jain. Hampshire: Palgrave.

Jepperson, Ronald, Alexander Wendt and Peter Katzenstein. 1996. Norms, Identity, and Culture in National Security. In The Culture of National Security: Norms and Identity in World Politics, 33-75. Edited by Peter Katzenstein. New York: Columbia University Press.

Kaldor, M. 2003. Global Civil Society. An Answer to War. UK: Polity.

Katzenstein, P. J. and Tsujinaka Y. 1995. Bullying, Buying, and Binding: USJapanese Transnational Relations and Domestic Structures. In Bringing Transnational Relations Back In: Non-State Actors, Domestic Structures and International Institutions, 79-111. Edited by T. Risse-Kappen. Cambridge: Cambridge University Press.

Keck, M. and K. Sikkink. 1998. Activists Beyond Borders: Advocacy Networks in International Politics. Ithaca: Cornell University Press.

Kingston, Jeff. 2004. Japan's Quiet Transformation. Social Change and Civil Society in the 21th century. London and New York: Routledge Curzon.

Kratochwil, Friedrich. 1982. On the Notion of 'Interest' in International Relations. International Organization 36(1):1-30.

Menju, T. and Takako Aoki. 1996. The evolution of Japanese NGOs in the Asia Pacific Context. In Emerging Civil Society in Asia Pacific Community, 143-164. Edited by

Tadashi Yamamoto. Singapore: Institute of Southeast Asian Studies; Tokyo: Japan Center for International Exchange in cooperation with the Asia Pacific Philanthropy Consortium (APPC). 
Migdal, Joel S. 1994. The State in Society: An approach to struggles for domination. Cambridge: Cambridge University Press.

- — 1997. Studying the State. In Comparative Politics: Rationality, Culture, and Structure, 208-235. Edited by M. I. Lichbach and A. S. Zuckerman. Cambridge: Cambridge University Press.

Miller, R. W. 1987. Fact and Method: Explanation, Confirmation, and Reality in the Natural and the Social Sciences. Princeton: Princeton University Press.

Mitchell, T. 1991. The Limits of the State: Beyond Statist Approaches and Their Critics. American Political Science Review, 85(1): 77-96.

Miyashita, Akitoshi. 2001. Consensus or Compliance? Gaiatsu, Interests, and Japan's Foreign Aid. In Japanese Foreign Policy in Asia and the Pacific, 37-61. Edited by Miyashita Akitoshi and Sato Yoichiro. New York: St. Martin's Press Palgrave.

Murphy, A. B. 1996. The Sovereign State System as Political-Territorial Ideal: Historical and Contemporary Considerations. Cambridge: Cambridge University Press.

Pekkanen, Robert. 2000. Japan's New Politics: The case of the NPO law. Journal of Japanese Studies 26(1): 111-148.

_-2006. Japan's Dual Civil Society. Members without advocates. Stanford: Stanford University Press.

Pharr, Susan J. 1994. Japanese Aid in the New World Order. In Japan. A new kind of Superpower?, 159-180. Edited by Craig Garby and Mary Brown Bullock. Washington, D.C.: The Woodrow Wilson Center Press and The Johns Hopkins University Press.

Pyle, K. B. 2006. Profound Forces in the Making of Modern Japan. Journal of Japanese Studies 32(2): 393-418.

Reimann, K. D. 2000. Civil Society and Official Development Assistance: International Politics, Domestic Structures and the Emergence of International Development NGOs in Japan. Working paper. Los Angeles, CA: International Studies Association.

—_ 2001. Late Developers in Global Civil Society: Domestic Barriers, International Socialization and the Emergency of International NGOs in Japan. Doctoral Disertation . Cambridge, Massachusetts, Harvard University.

- - 2003. Building Global Civil Society from the Outside In? Japanese International Development NGOs, the State, and International Norms. In 
The State of Civil Society in Japan, 298-315. Edited by Frank J. Schwartz and Susan J. Pharr. Cambridge: Cambridge University Press.

Risse-Kappen, T. 1995. Bringing Transnational Relations Back In: Introduction. In Bringing Transnational Relations Back In: Non-State Actors, Domestic Structures and International Institutions, 3-33. Edited by T. Risse-Kappen. Cambridge: Cambridge University Press.

- - 2000. "Let's Argue!": Communicative Action in World Politics. International Organization 54(1): 1-39.

Rix, Alan.1980. Japan's Economic Aid. Policy-making and Policy. London: Croom Helm.

1993. Japan's foreign aid challenge. London and New York, Routledge.

Ruggie, John Gerard. 1998. Constructing the World Polity: Essays on International Institutionalization. Nueva York: Routledge.

Schereurs, Miranda. 2002. Environmental Politics in Japan, Germany and the United States. Cambridge: Cambridge University Press.

Searle, J. R. 1995. The Construction of Social Reality. New York: Free Press. Strang, D. 1996. Contested Sovereignty: The Social Construction of Colonial Imperialism. Cambridge: Cambridge University Press.

Tarrow, S. 1996. Fishnets, Internets and Catnets: Globalization and Transnational Collective Action. Estudios/Working Papers. Madrid.

Uchida, Yasuo. 1996. Japan: Public Knowledge and Attitudes towards ODA. In Public Support for International Development, 85-92. Edited by Colm Foy and Henny Helmich, Development Centre of the Organization for Economic Co-operation and Development.

Ullman-Margalit, Edna. 1977. The Emergence of Norms. Oxford: Clarendodon Press.

Van Rooy, Alison. 1997. The frontiers of influence: NGO lobbying at the 1974 World Food Conference, the 1992 Earth Summit and beyond. World Development 25(1): 93-114.

Walzer, M. 1995. The Concept of Civil Society. In Toward a Global Civil Society, 7-27. Edited by M. Walzer. Providence: Berghan Books.

Wendt, Alexander. 1992. Anarchy is what states make of it: The social construction of power politics. International Organization 46(2):391-425.

- - 1995. Constructing International Politics. International Security 20(1): 71-81.

White, John. 1974. The Politics of Foreign Aid. New York: St. Martin's Press. 